\title{
Observance of COVID 19 Protocols and Effective Use of Library Resources and Services in the State Universities in North Central, Nigeria
}

\author{
Nathaniel Agbo Oche \\ Department of Library and Information Science, Benue State Polytechnic, Ugbokolo, Nigeria
}

Email address:

nathanieloche@gmail.com

\section{To cite this article:}

Nathaniel Agbo Oche. Observance of COVID 19 Protocols and Effective Use of Library Resources and Services in the State Universities in North Central, Nigeria. American Journal of Information Science and Technology. Vol. 5, No. 1, 2021, pp. 12-18.

doi: 10.11648/j.ajist.20210501.12

Received: December 24, 2020; Accepted: January 6, 2021; Published: January 23, 2021

\begin{abstract}
The emergence of COVID 19 has led to total or partial lockdown around the world, thereby restricting movements as well as physical contacts. COVID 19 could be contracted through touching infected book shelves, books, catalogue cabinet, reading carrels and tables, among others. At the same time, adequate information is required to prevent and manage the virus from spreading. The study examined the observance of COVID-19 protocols and effective use of library resources and services in State Universities in North Central, Nigeria. Descriptive survey research design was adopted for the study. The population of the study is 163 library staff. This comprised of the entire library staff in the six state owned universities in North Central, Nigeria. Online survey was conducted using Google form between $15^{\text {th }}$ and $14^{\text {th }}$ of December, 2020. The link to the Google form was shared via individual and group social media platforms of the staff so as to increase the response rate. Data collected was analyzed using frequency distribution table, chart, percentage and mean with the aid of SPSS version 23. The findings revealed among other things that; library services are poorly provided by university libraries during COVID-19 lockdown in state owned university libraries in North Central, Nigeria. Majority of the respondents agreed that their library posted updates about COVID-19 on library blog, websites, portals etc. and use of social media for library services delivery during COVID-19 pandemic lockdown. Other services like; Ask Librarian virtual reference service, electronic delivery service, providing access to e-books, providing access to e-journals, providing OPAC as tool for browsing and searching the library collection, providing access to students' electronic thesis and dissertation, electronic Newspaper Clipping Depository and so on were poorly provided. Also, it was revealed that the observance of COVID-19 protocols affected effective use of library resources and services. It was also revealed that; erratic power supply, lack of adequate electronic resources in the library, lack of funds to fumigate library environment, lack of internet access in the library, nonchalant attitude of staff towards observing COVID-19 protocols, lack of adequate accommodation in the library to observe social distancing, and inadequate digital skills to adopt online services and so on, as major challenges. The study however, recommended among other things that; the library management should provide adequate digital skills training to their staff so as to adopt online services in this COVID-19 period. Adequate infrastructural facilities should be made available and accessible.
\end{abstract}

Keywords: COVID-19 Protocols, Library Resources, Library Services, State University libraries, North Central, Nigeria

\section{Introduction}

\subsection{Background to the Study}

University libraries are libraries attached to universities for the purpose of making information resources and services available and accessible to staff, students and external researchers. A University library is an important academic unit in higher education because it provides information in various formats to support the teaching, learning and research objectives of the university. It is the information nervous system of the university. University 
libraries acquire library resources for use by the user community [1]. Library information resources include the print and electronic information resources that are acquired, processed, organized and disseminated to the entire users' community to support their academic activities. Information resources are print or electronic resources which contain information needed for meeting the needs of library users. Library resources include the print and electronic information resources that are acquired, processed, organized and disseminated to the entire users' community to support their academic activities. Library resources are books, dictionaries, encyclopedias, journals, magazines, newspapers, maps, directories, bibliographies, biographies, e-books, e-newspapers, e-journals, literature materials among others [2]. These resources are used to deliver effective services to the users whose information needs must be met by the library for continues patronage and relevance of the university libraries.

Library and information services include cataloguing, classification, charging, discharging, reference and information services, user education, serial services, inter-library loan among others. These services are provided to satisfy users information needs. According to other researchers, library and information services are those facilities, which are provided by libraries and information centers for the use of library resources and dissemination of information. In so doing, users' information needs are met [3]. Users visit the university libraries to either use the library resources or enjoy their services, however, COVID 19 pandemic led to observing certain protocols and guidelines which might affect effective use of the resources and services in university libraries.

The emergence of COVID 19 has led to total or partial lockdown around the world, thereby restricting movements as well as physical contacts. World Health Organisation (WHO) recommended protocols to prevent the deadly virus such as social distancing, frequent washing of hands, wearing of face mask, avoiding touching surface, and so on. Most importantly, COVID 19 could be contracted through touching infected book shelves, books, catalogue cabinet, reading carrels and tables, among others. At the same time, adequate information is required to prevent and manage the virus from spreading. Efforts to contend with the pandemic involved international and local travel restrictions, screening, selfisolation, quarantine, closure of markets and schools including library services [4]. These resources the library resources becomes useless. The use of library information resources and services has been a concern from the time libraries changed from being cultural monuments to knowledge acquisition and information communication centers [5].

It is the foregoing background that motivated the present study to examine whether or not the observance of COVID19 protocols affects effective use of library resources and services in the State Universities in North Central, Nigeria, where similar study has not been conducted to the best knowledge of the researcher.

\subsection{Statement of the Problem}

Effective use of library resources and services are the fundamental objective of university libraries as the information needs of users must be met. However, the emergence of COVID-19 presented a situation where university libraries must be innovative and creative to meet the information needs of their users. To effectively use the library, the users must be comfortable and the atmosphere must be conducive. Observance of COVID-19 protocols like social distancing, wearing face mask, regular washing of hands, among others might affect the comfort of the users thereby discouraging them from using university library resources and services during the COVID-19 period. There is the need to examine if observing COVID-19 protocols affect effective use of library resources and services from the point of view of library staff in North Central, Nigeria.

\subsection{Purpose of the Study}

The main purpose of the study is to examine observance of COVID-19 protocols and effective use of library resources and services in the State Universities in North Central, Nigeria. The specific purposes of the study are to:

1. Examine the library services provided during COVID 19 period by State Universities in North Central, Nigeria.

2. Ascertain impact of observing COVID 19 on effective use of library resources and services in the State Universities in North Central, Nigeria.

3. Identify the challenges associated with observing COVID19 protocols and effective use of library resources and services in the State Universities in North Central, Nigeria.

4. Proffer strategies that can be adopted towards effective use of library resources and services while observing COV1D19 protocol in State Universities in North Central, Nigeria.

\section{Literature Review}

To slow down the COVID-19 pandemic, colleges and universities have been asked to shut down and make immediate transitions of moving education to online learning if possible. This has posed a challenge for libraries, users including teaching faculty and students, as well as the services the library has been providing during the prepandemic period. According to some researchers, in this pandemic situation of COVID 19, the physical library systems are totally stuck due to maintaining the rules of social distancing so as to help overcome the spread of virus infection [6]. It was observed that due to COVID-19 protocols, Clement C. Maxwell Library, Bridgewater State University has reduced the opening hours, number of staff that come to work, number of users that visit the library, the library building is accessible with only one door open, group study rooms are currently not in use and so on, In order to observe COVID-19 protocols library staff were reduced and on rotational basis [7]. Also, Mestri stated that, Libraries in the World are facing hard problem of providing library services ranging from continuing existing services 
or some of them or full closure [15]. It is difficult to match the library services with the government decisions and intensity of the pandemic in different part of the area.

In addition, running water, liquid soap and hand sanitizers were provided at the entrance of the library for everyone entering the library and it is also compulsory for every staff to wear face mask [8]. Before the emergence of the COVID19 pandemic, several libraries have traditionally provided library services to users in manual and print format while few others opted for digital collection. However, with the lockdown imposed on every sector including the library, the inefficiency of most libraries in continuing her provision of useful and up to date library services to her users have been exposed [14].

All over the world, library professionals are facing different challenges with resources and services to offer and how to handle these situations of lockdown, ranging from minimal restrictions to full closure of libraries. University libraries globally, in a bid to find alternative approaches to delivery of library services and resources in response to the COVID-19 pandemic, are adopting increasing access to digital resources and services to address the information needs of their patrons [6]. The traditional approaches were given up, and new approaches were identified and implemented in response to the current situation [9]. Some researchers observed that due to COVID-19 pandemic, libraries have experienced closure or restricted their services. The authors further stated that libraries can strengthen online services to provide access to their resources, most especially through social media platforms [10]. In this pandemic situation, the role of the library professional is most important to serve the whole community through a digital platform via technologies. Also, by following the government COVID-19 guidelines library professionals can break the chain of coronavirus by providing different digital information services remotely via technologies on the web [6].

In the presence of COVID-19, it is advisable to promote online services in order to limit physical visits to the library. This can be achieved through the deployment of digital resources e.g. e-books, e-journals, e-newspapers, e-audio books, etc. Others are online instruction and virtual programmes [4]. Libraries have been under closure due to lockdown enforced as a measure to tackle COVID-19. The study also revealed that 'Access to open access resources' is the most delivered library service during lockdown [11]. In another study, it was discovered that the major challenges associated with provision of library resources and services during COVID-19 are of working from home, poor infrastructure and lack of working space, as well as data subscription was paid from staff pockets. They further recommended that, electronic gadgets that support social media platforms be acquired and data be subscribed for the purpose of the prescribed library function it was designated to achieve [12]. The experience of Nimbe Adedipe library, Federal University of Agriculture, Abeokuta in the delivery of services indicated that information literacy training were conducted for users through Zoom, Skype and Google meet, especially for staff from time to time [8].

\section{Methodology}

Descriptive survey research design was adopted for the study. It is a study which aims at collecting data, describing in a systematic manner, the characteristics, features or facts about a given population [13]. This design was deemed most suitable for this study as the study was designed to describe systematically, data and facts on observance of COVID-19 protocols and effective use of library resources and services in the State Universities in North Central, Nigeria. The population of the study is 163 library staff. This comprised of the entire library staff in the six state owned universities in North Central, Nigeria. Online survey was conducted using Google form between $15^{\text {th }}$ and $14^{\text {th }}$ of December, 2020. The link to the Google form was shared via individual and group social media platforms of the staff so as to increase the response rate. Data collected were analyzed using frequency distribution table, chart, percentage and mean with the aid of SPSS version 23. The decision rule for acceptance or rejection of the idea covered by an item, on the basis of the mean score of respondents was a benchmark of ' 2.50 '. This implies that a respondents' mean score of 2.49 and below in an item, indicates disagreement/rejection of the view of an item, while a mean score of '2.50' and above implied acceptance of the said item.

\section{Results}

A total of 132 library staff responded to the survey, this shows a response rate of $81 \%$ which is valid for study.

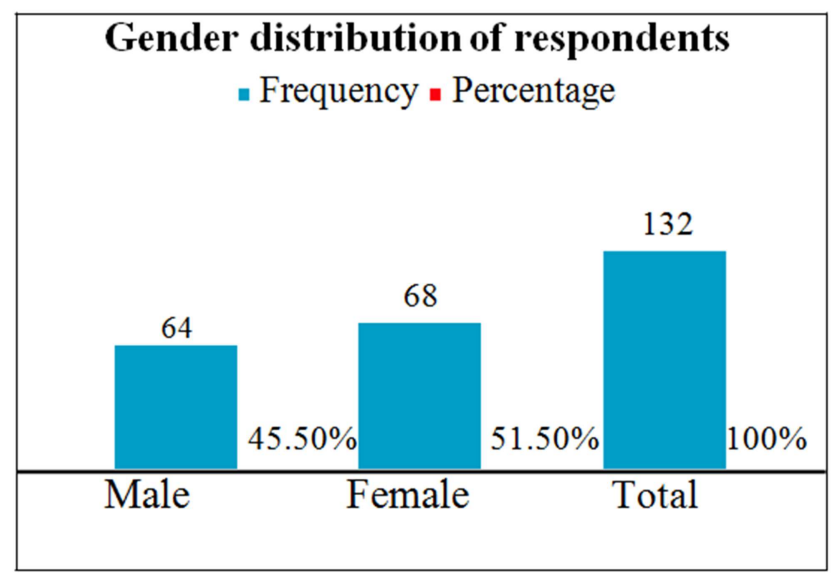

Figure 1. Gender Distribution of Respondents.

Figure 1 represents the gender distribution of respondent. Based on the chart, out of 132 respondents studied, 64 $(48.5 \%)$ are male. While $68(51.5 \%)$ are female. 


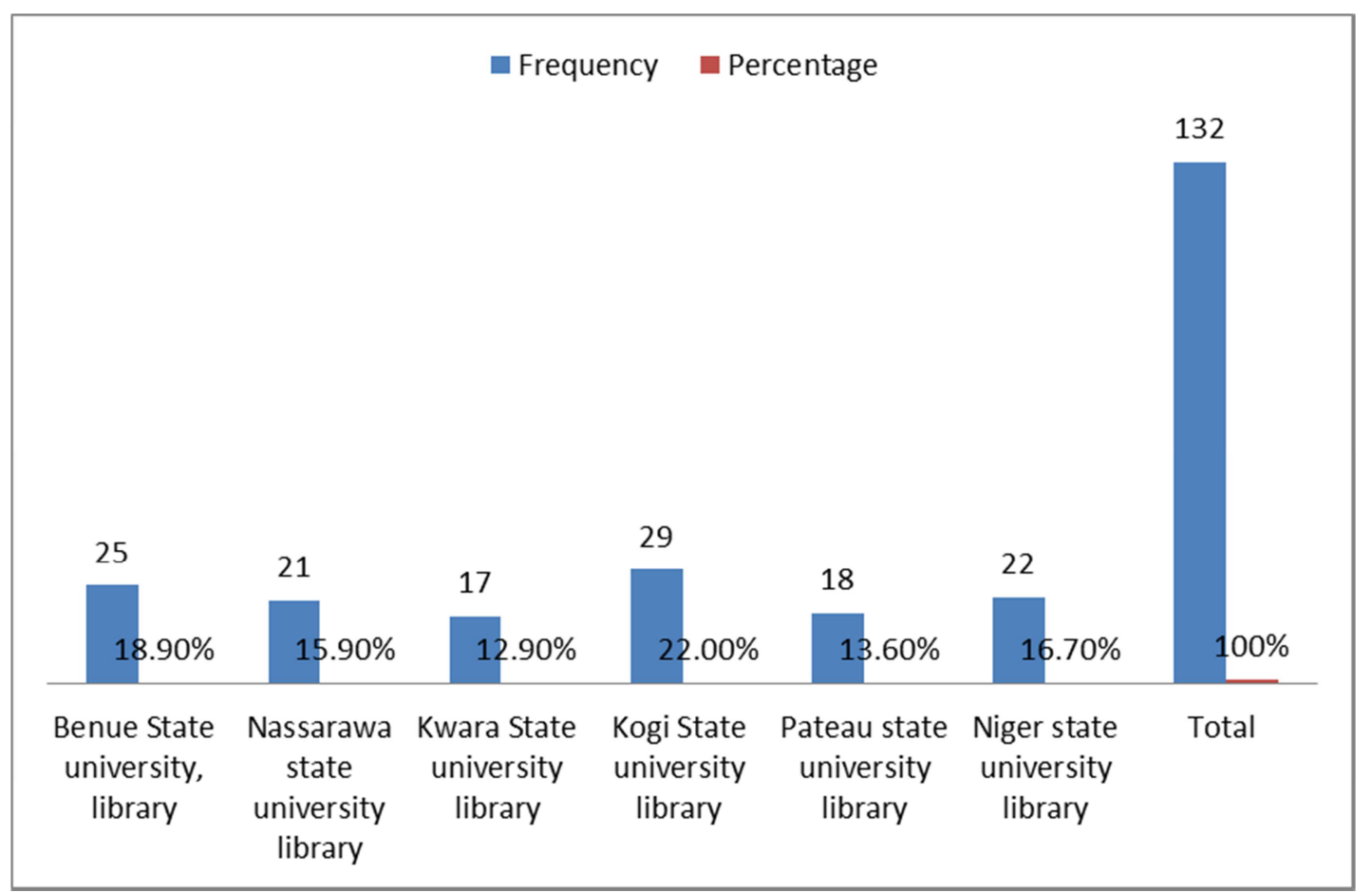

Figure 2. Distribution of Respondents based on Institutions.

From the results, most of the library services presented were not adequately provided during COVID-19 pandemic. Only 45 (34.1\%) library staff provided Ask librarian virtual reference services. $38(28.8 \%)$ provided electronic, $54(40.9 \%)$ provided access to e-books, 54 (40.0\%) provided access to e-journals, 41 (31.1) provided OPAC as tools for browsing\& searching the library collection, $45(34.1 \%)$ provided access to students electronic thesis and dissertation, $59(44.7 \%)$ provided electronic newspaper clipping depository, $69(52.3 \%)$ provided the use of social median for library services, $43(32.6 \%)$ provided health information on COVID-19, 34 (25. 8\%) provided online library instructions and promotes media literacy, 77 (58.3\%) provided posting updates about COVID-19 on library blog, facebook page, websites, portal etc.

Table 1. Mean responses of library staff on how observance of COVID-19 protocols affects effective use of library resources in their library.

\begin{tabular}{|c|c|c|c|c|c|c|c|c|c|}
\hline $\mathbf{S} / \mathbf{N}$ & Items their & SA & $\mathbf{A}$ & D & SD & $\mathbf{X}$ & SD & $\mathbf{R}$ & Decision \\
\hline 1 & Wearing face mask makes users uncomfortable while reading & 132 & 0 & 0 & 0 & 4.00 & 0.00 & $1^{\text {st }}$ & Accepted \\
\hline 2 & Charging and discharging was suspended so as to prevent the materials from been affected. & 101 & 31 & 0 & 0 & 3.77 & 0.43 & $2^{\text {nd }}$ & Accepted \\
\hline 3 & social distancing has affected Group studying & 100 & 32 & 0 & 0 & 3.76 & 0.43 & $3^{\text {rd }}$ & Accepted \\
\hline 4 & With COVID-19 protocols some services are not offered in the library & 95 & 37 & 0 & 0 & 3.72 & 0.45 & $4^{\text {th }}$ & Accepted \\
\hline 5 & $\begin{array}{l}\text { Some library resources are not available due to fear of being affected thus, are quarantined } \\
\text { for some days. }\end{array}$ & 93 & 39 & 0 & 0 & 3.70 & 0.46 & $5^{\text {th }}$ & Accepted \\
\hline 6 & Library opening hours have been reduced so as to observe COVID-19 protocols & 77 & 45 & 10 & 0 & 3.5 & 0.64 & $6^{\text {th }}$ & Accepted \\
\hline 7 & Number of users in the reading room have been reduced & 71 & 50 & 11 & 0 & 3.45 & 0.66 & $7^{\text {th }}$ & Accepted \\
\hline 8 & $\begin{array}{l}\text { The whole re-arrangement of library due to COVID-19 protocols discourages effective use } \\
\text { of library resources }\end{array}$ & 66 & 47 & 19 & 0 & 3.36 & 0.72 & $8^{\text {th }}$ & Accepted \\
\hline 9 & Having audience with the reference librarian is now online (no face to face contact) & 46 & 9 & 45 & 32 & 2.98 & 0.87 & $9^{\text {th }}$ & Accepted \\
\hline
\end{tabular}

Table 1 shows the mean responses of library staff on how observance of COVI-19 protocols affects the effective use of library resources in their library. Based on the table, the major COVID-19 protocols that affect effective use of library resources are; wearing face mask makes users uncomfortable while reading with 4.00 mean score, charging and discharging was suspended so as to prevent the material from been affected with 3.77 mean score. Social distancing has affected group studying with 3.76 mean score, with COVID19 protocols some services are not offered in the library with
3.72 mean score, some library resources are not available due to fear of being affected thus, are quarantined for some days with 3.70 mean score, library opening hours have been reduced so as to observe COVID-19 protocols with 3.51 mean score, number of users in the reading room have been reduced with 3.45 mean score, the whole re-arrangement of library due to COVID-19 protocols discourages effective use of library resources with 3.36 mean score and having audience with the reference librarian is now online (no face to face contact) with 2.98 mean score. 
Table 2. Mean response of library staff on the challenges associated with observing COVID-19 Protocols in their library.

\begin{tabular}{|c|c|c|c|c|c|c|c|c|c|}
\hline $\mathbf{S} / \mathbf{N}$ & Items & SA & $\mathbf{A}$ & D & SD & Mean & SD & Rank & Decision \\
\hline 1 & Erratic power supply & 132 & 0 & 0 & 0 & 4.00 & 0.00 & $1^{\text {st }}$ & Accepted \\
\hline 2 & Lack of electronic resources in the library & 132 & 0 & 0 & 0 & 4.00 & 0.00 & $1^{\mathrm{st}}$ & Accepted \\
\hline 3 & Lack of funds to fumigate library environment & 100 & 32 & 0 & 0 & 3.77 & 0.42 & $2^{\text {nd }}$ & Accepted \\
\hline 4 & Lack of internet access in the library & 98 & 34 & 0 & 0 & 3.74 & 0.44 & $3^{\text {rd }}$ & Accepted \\
\hline 5 & Nonchalant attitude of staff towards observing COVID-19 protocols & 92 & 33 & 7 & 0 & 3.64 & 0.58 & $4^{\text {th }}$ & Accepted \\
\hline 6 & Lack of adequate accommodation in the library to observe social distancing & 83 & 49 & 0 & 0 & 3.63 & 0.48 & $5^{\text {th }}$ & Accepted \\
\hline 7 & Lack of library social media page for posting COVID-19 related information & 81 & 43 & 8 & 0 & 3.55 & 0.61 & $6^{\text {th }}$ & Accepted \\
\hline 8 & Inadequate digital skills to adopt online services & 46 & 44 & 37 & 5 & 2.99 & 0.89 & $7^{\text {th }}$ & Accepted \\
\hline 9 & Lack of hand sanitizers in the library & 43 & 42 & 37 & 10 & 2.89 & 0.95 & $8^{\text {th }}$ & Not Accepted \\
\hline 10 & Lack of running water tap in the library for regular washing of hands & 5 & 3 & 94 & 30 & 2.64 & 1.21 & $9^{\text {th }}$ & Not Accepted \\
\hline
\end{tabular}

Table 2 shows the mean response of library staff on the challenges associated with observing COVID-19 Protocols in their library. from the table the major challenges with observing COVID-19 protocols in library are: erratic power supply with 4.00 mean score, lack of electronic resources in the library with 4.00 mean score, lack of funds to fumigate library environment with 3.77 mean score, lack of internet access in the library with 3.74 mean score, nonchalant attitude of staff towards observing COVID-19 protocols with 3.64 mean score with 3.63 mean score, lack of library social media page for posting COVID-19 related information with 3.55 mean score, inadequate digital skills to adopt online services with 2.99 mean score, lack of hand sanitizers in the library with 2.89 mean score and lack of running water tap in the library for regular washing of hands with 2.64 mean score.

Table 3. Mean responses of library staff on the strategies that can be adopted towards effective use of library resources and services while observing COV1D19 protocol.

\begin{tabular}{|c|c|c|c|c|c|c|c|c|c|}
\hline $\mathbf{S} / \mathbf{N}$ & Items & VA & $\mathbf{A}$ & $\mathbf{L A}$ & NA & Mean & SD & Rank & Decision \\
\hline 1 & Provision of hand sanitizers in the library & 72 & 0 & 0 & 0 & 4.00 & 0.00 & $1^{\text {st }}$ & Accepted \\
\hline 2 & Adequate digital skills training of staff to adopt online services & 72 & 0 & 0 & 0 & 4.00 & 0.00 & $1^{\text {st }}$ & Accepted \\
\hline 3 & Constant power supply in the library & 72 & 0 & 0 & 0 & 4.00 & 0.00 & $1^{\mathrm{st}}$ & Accepted \\
\hline 4 & Providing access to electronic resources in the library & 72 & 0 & 0 & 0 & 4.00 & 0.00 & $1^{\text {st }}$ & Accepted \\
\hline 5 & Creating library social media page for posting COVID-19 related information & 72 & 0 & 0 & 0 & 4.00 & 0.00 & $1^{\text {st }}$ & Accepted \\
\hline 6 & Provision of adequate internet access in the library & 71 & 1 & 0 & 0 & 3.77 & 0.42 & $2^{\text {nd }}$ & Accepted \\
\hline 7 & Provision of running water tap in the library for regular washing of hands & 70 & 2 & 0 & 0 & 3.76 & 0.43 & $3^{\text {rd }}$ & Accepted \\
\hline 8 & Provision of adequate accommodation in the library to observe social distancing & 68 & 4 & 0 & 0 & 3.74 & 0.44 & $4^{\text {th }}$ & Accepted \\
\hline 9 & Provision of adequate funds to fumigate library environment & 63 & 9 & 0 & 0 & 3.70 & 0.46 & $5^{\text {th }}$ & Accepted \\
\hline 10 & $\begin{array}{l}\text { Proactive attitude of staff towards observing COVID-19 protocols in the library } \\
\text { protocols in the library }\end{array}$ & 62 & 10 & 0 & 0 & 3.69 & 0.46 & $6^{\text {th }}$ & Accepted \\
\hline
\end{tabular}

Table 3 shows the mean respondents of library staff on the strategies that can be adopted towards effective use of library resources and services while observing COV1D-19 protocol. From the table, the major strategies that can be adopted towards effective use of library resources and services while observing COV1D-19 protocol are as follows: provision of hand sanitizers in the library with 4.00 mean score, adequate digital skills training of staff to adopt online services with 4.00 mean score, constant power supply in the library with 4.00 mean score, providing access to electronic resources in the library with 4.00 mean score, creating library social media page for posting COVID-19 related information with 4.00 mean score, provision of adequate internet access in the library with 3.77 mean score, provision of running water tap in the library for regular washing of hands with 3.76 mean score, provision of adequate accommodation in the library to observe social distancing with 3.74 mean score, provision of adequate funds to fumigate library environment with 3.70 mean score and proactive attitude of staff towards observing COVID-19 protocols in the library with 3.69 mean score.

\section{Discussion of the Findings}

The findings revealed that library services are poorly provided by university libraries during COVID-19 lockdown in the State owned University libraries in North Central, Nigeria. Majority of the respondents agreed that their library posted updates about COVID-19 on library blog, websites, portals etc. and use of social media for library services delivery during COVID-19 pandemic lockdown. Other services like; Ask Librarian virtual reference service, electronic delivery service, providing access to e-books, providing access to e-journals, providing OPAC as tool for browsing \& searching the library collection, providing access to students' electronic thesis and dissertation, electronic Newspaper Clipping Depository, providing health information on COVID-19 and providing online library instructions and promoting media literacy were poorly provided in the State University libraries in North Central, Nigeria during COVID-19 lockdown. This scenario partly corresponds with the assertion of Bhati \& Kumar that, in this 
pandemic situation of COVID 19, the physical library systems are totally stuck due to maintaining the rules of social distancing and also help to overcome the spread of virus infection [6].

The findings revealed that the observance of COVID-19 protocols affected effective use of library resources and services in State University libraries in North Central, Nigeria. It was gathered among other things that; wearing face mask makes users uncomfortable while reading, charging and discharging was suspended so as to prevent the materials from been effected, social distancing has affected group studying, with COVID-19 protocols some services are not offered in the library, some library resources are not available due to fear of being affected thus, are quarantined for some days, library opening hours have been reduced so as to observe COVID-19 protocols, numbers of users in the reading room have been reduced, the whole re-arrangement of library due to COVID-19 protocols discourages effective use of library resources, and having audience with the reference librarian is now online (no face to face contact). The findings are in accordance with those of two researchers who discovered that, due to COVID-19 protocols, Clement C. Maxwell Library, Bridgewater State University reduced the opening hours, number of staff that come to work, number of users that visit the library, the library building is accessible with only one door open, group study rooms are currently not in use and so on [7].

It was also revealed that; erratic power supply, lack of adequate electronic resources in the library, lack of funds to fumigate library environment, lack of internet access in the library, nonchalant attitude of staff towards observing COVID-19 protocols, lack of adequate accommodation in the library to observe social distancing, lack of library social media page for posting COVID-19 related information, and Inadequate digital skills to adopt online services are the major challenges associated with observing COVID - 19 Protocols in the State Universities libraries in North Central, Nigeria. The findings above further validate the assertion of [6] that, all over the world, Library Professionals are facing different challenges with resources and services to offer and how to handle these situations of lockdown, ranging from minimal restrictions to full closure of libraries. The findings also corresponds with that of [12] who discovered that the major challenges associated with provision of library resources and services during COVID-19 are inadequacies of working from home, poor infrastructure and lack of working space, as well as data subscription been paid from staff pockets.

Finally, the findings revealed that, provision of hand sanitizers in the library, adequate digital skills training of staff to adopt online services, constant power supply in the library, providing access to electronic resources in the library, creating library social media page for posting COVID-19 related information, provision of adequate internet access in the library, provision of running water tap in the library for regular washing of hands, provision of adequate accommodation in the library to observe social distancing, provision of adequate funds to fumigate library environment, and proactive attitude of staff towards observing COVID-19 protocols in the library are the major strategies that can be adopted towards effective use of library resources and services while observing COV1D-19 protocol in state universities in North Central, Nigeria. The findings partly correspond with the recommendations suggested by [12] that, electronic gadgets that support social media platforms be acquired and data be subscribed for the purpose of the prescribed library function it was designate to achieve.

\section{Conclusion}

The study examined observance of COVID-19 protocols and effective use of library resources and services in the State Universities in North Central, Nigeria. Based on the findings the study concluded that, state university libraries in North Central Nigeria only posted updates about COVID-19 on library blog, websites, portals etc. and use of social media for library services delivery during COVID-19 pandemic lockdown. Other services and resources such as Ask Librarian virtual reference service, electronic delivery service, providing access to e-books, providing access to e-journals among others were poorly provided. The study also concluded observance of COVID-19 protocols greatly affected effective use of library resources and services in State Universities in North Central, Nigeria. As regards to the major challenges associated with observing COVID-19 Protocols in State Universities in North Central, Nigeria, the study identified erratic power supply, lack of adequate electronic resources in the library, Lack of funds to fumigate library environment, lack of internet access in the library, nonchalant attitude of staff towards observing COVID-19 protocols and lack of adequate accommodation in the library to observe social distancing, and so on.

\section{Recommendations}

Based on the conclusion reached, the following recommendations were made:

1. The library management should provide adequate digital skills training to their staff so as to adopt online services in this COVID-19 period and beyond

2. Adequate infrastructural facilities should be made available and accessible in State University libraries.

3. Providing access to electronic resources in the library through subscriptions or via providing open access links for the users

4. Constant power supply should be provided by the State University library management

5. Adequate funding should be made available for libraries to fumigate their environment from time to time, acquire temperature scanners and hand sanitizers, among others. 


\section{References}

[1] Onah, J. C., Adayi, I. O., Okonkwo, E. A., and Onyebuchi, G. $\mathrm{U}$. Information retrieval skills as it correlates to undergraduate use of library information resources at a Nigerian university. Library Philosophy and Practice (e-journal). 2020, 4586. https://digitalcommons.unl.edu/libphilpr ac/4586.

[2] Aina, L. O. Library and Information Science Text for Africa. Ibadan: Third world information services, 2004.

[3] Tella, A. \& Ojo, R. R. Marketing Library and Information Services for effective utilization of available resources: the $21^{\text {st }}$ century librarians and information professionals-which ways and what works? In Tell, A. \& Issa, A. O. (Eds). Library and Information Science in Developing Countries: Contemporary issues. Hershey: Information Science Reference, 2012.

[4] Adayi, O. I., Idoko, R., Odeh, O. A. and Onah, C. J. Creative adaptation strategies for effective library services in Nigeria: a response to mitigate covid-19 pandemic. Journal of Management and Technology, 2020, 16: 1-8.

[5] Mwatela, W. M. Factors influencing utilization of library services and resources: the case of university of Nairobi Mombasa campus library. Unpublished project submitted to the department of extra Mural studies, University of Nairobi, 2013.

[6] Bhati, P. \& Kumar, I. Role of Library Professionals in a Pandemic Situation like COVID-19. International Journal of Library and Information Studies, 2020, 10 (2): 33-48.

[7] Mehta, D. \& Wang, X. COVID-19 and digital library services - a case study of a University library. Digital Library Perspectives. $2020 \mathrm{https} / /$ www.emerald.com/insight/20595816.htm7] Mehta, D. \& Wang, X. COVID-19 and digital library services - a case study of a University library. Digital
Library Perspectives.

https://www.emerald.com/insight/2059-5816.htm.

2020

[8] Onifade, F. N. Library Services during COVID-19 Period: Federal University of Agriculture, Abeokuta Experience, International Information \& Library [Review. 2020 DOI: 10.1080/10572317.2020.1834247.

[9] LIBER statement on COVID 19," EUA. 2020. Retrieved from https://eua.eu/news/491:liber-statementon-covid-19.html.

[10] Ladan, A., Haruna, B. and Madu, A. U. COVID-19 Pandemic and Social Media News in Nigeria: The Role of Libraries and Library Associations in Information Dissemination. International Journal of Innovation and Researchin Educational Sciences. 2020, 7 (2): 2349-5219.

[11] Neog, S. Library Services through Social Media during Lockdown due to COVID-19 with Special Reference to University Libraries of Assam". 2020. Library Philosophy and Practice (e-journal). 4262. https://digitalcommons.unl.edu/li bphilprac/4262.

[12] Kasa, M. G., and Yusuf, A. Experience of an academic library during the covid-1 9 pandemic". 2020. Library Philosophy and Practice (e-journal). 4456. https://digitalcommons.unl.edu/li bphilprac/4456.

[13] Nworgu, B. G. Educational Research: Basic issues and methodology ( $3^{\text {rd }}$ ed.). Nsukka: University Trust Publishers, 2015.

[14] Friday, J., Chidozie, O., \& Chukwuma, L. N. (2020) Social media and library services: a case of COVID-19 pandemic era. International Journal of Research and Review. 2020; 7 (10): 230-237.

[15] Reopening libraries in COVID 19 pandemic: challenges and recommendations. IP Indian Journal of Library Science and Information Technology, 5 (1): $16-23$. http://doi.org/10.18231/j.ijlsit.2020.004. 